\title{
APLEISTU PASTATŲ RACIONALAUS NAUDOJIMO MODELIAVIMAS TAIKANT GEOINFORMACINES SISTEMAS
}

\author{
Jurgita Antuchevičienė \\ Statybos technologijos ir vadybos katedra, Vilniaus Gedimino technikos universitetas, \\ Sauletekio al. 11, LT-10223 Vilnius-40, Lietuva \\ el. paštas: Jurgita.Antucheviciene@st.vtu.lt
}

Iteikta 200504 07, priimta 20051005

\begin{abstract}
Santrauka. Priimant erdvinius sprendimus geografinių informacinių sistemų (GIS) galimybės taikomos apleistų pastatų racionalaus naudojimo problemoms aplinkos ir visuomenès darnos požiūriu spręsti. Pasiūlytas pradinių duomenu parengimo ir jų taikymo skaičiavimams daugiatiksliais sprendimu prièmimo (Multi-attribute Decision Making - MADM) metodais modelis. Pateikta apleistu pastatų duomenų bazès struktūra ir parengtas šios bazès pildymo duomenimis apie nenaudojamus Lietuvos kaimo statinius pavyzdys. Sudaryti darnią ūkio plètrą šalyje nusakančiu socialinių, ekonominių ir aplinkos rodiklių sluoksniai. Numatytos duomenu analizès galimybės. Pateiktas GIS ir daugiatikslio sprendimu prièmimo metodo TOPSIS (Technique for the Order Preference by Similarity to Ideal Solution) integravimo racionaliam apleistų pastatų Lietuvos kaimo vietovėse naudojimui modeliuoti pavyzdys.
\end{abstract}

Raktažodžiai: geografinès informacinès sistemos (GIS), daugiatiksliai sprendimu prièmimo metodai (MADM), arčiausiojo priartèjimo prie idealiojo taško metodas (TOPSIS), apleistieji pastatai, darni plètra, alternatyvų prioritetu nustatymas.

\section{Ivadas}

Apleistieji pastatai yra grèsmingi antropogeninio kraštovaizdžio vizualinès taršos objektai, keliantys pavojų žmonių saugumui, socialinę ittampą, dèl jų patiriami materialiniai nuostoliai. Tokių pastatų racionalaus tvarkymo problemą būtina spręsti kompleksiškai, ivvertinant technines ir netechnines sąlygas, t. y. laikantis teritorijų ir visuomenès darnos principo. Siekiant procesą optimizuoti, reikia imtis atitinkamų sprendimų rèmimo priemonių, taikyti informacines technologijas, kurios padètų kaupti, analizuoti bei atnaujinti aktualią informaciją ir objektyviai ivertinti statiniu tvarkymo galimybes bei alternatyvius variantus.

Norint išsamiai apibūdinti apleistų pastatų tvarkymo alternatyvas minètosios darnos požiūriu, būtina jas aprašyti apibendrinant ekonominius, ekologinius, socialinius, inžinerinius-techninius ir kitus duomenis apie objektą bei jo buvimo vietą. Duomenims kaupti, apdoroti ir pateikti vartotojui gali būti naudojamos ivvairaus pobūdžio informacinès sistemos. Problemoms, susijusioms su lokalizacija, spręsti dažnai taikomos geografinès informacinès sistemos (GIS). Šiose sistemose tradicinè erdvinių planavimo ir valdymo sprendimu prièmimo technika - teminių sluoksnių sanklotos [1]. Tačiau sluoksnių sanklotos analizė turi keletą trūkumų: skaitmeninių žemėlapių sluoksnių sanklotą, priimant sprendimus, patogu taikyti tik tuomet, kai alternatyviems variantams apibūdinti rodiklių per mažai, daugeliu atvejų neįmanoma atsižvelgti i aplinkybę, kad tam tikrų sluoksnių informacija gali būti nevienodai svarbi. Šių trūkumų galima išvengti taikant daugiatikslių sprendimų prièmimo $(M A D M)$ technologijas [2-4 ir kt.]. Jos pakeičia ar papildo standartines sluoksnių sanklotas. GIS ir $M A D M$ integravimas itin tinka ir aktualu darnios teritorijų plètros uždaviniams spręsti, esant daugeliui suinteresuotų grupių bei konfliktuojant interesams [5]. Tradicinis GIS taikymas bei šios srities mokslinès publikacijos susiję su žemės naudojimo planavimu [6, 7], objektų statybos vietos parinkimu [8-10]. Vèlesni darbai dažnai skirti įvairiems žemès naudojimo ekologiniams ir aplinkosaugos aspektams spręsti, analizuojant kelias potencialiai galimas alternatyvas [11-15].

Nepaisant GIS ir MADM derinimo pavyzdžių mokslinejje literatūroje, pasak J. Malczewski [16], nors dauguma erdvinių problemu iš prigimties yra daugiatikslès, apimančios ekonominius, socialinius, gamtinius ir kitus aspektus bei lemiančios interesų susidūrimą, daugiatikslių sprendimų prièmimo procesas nèra labai plačiai žinomas, visuotinai pripažistamas ir efektyviai integruojamas erdvinès analizès bei geografinių informacinių sistemų srityje. Lietuvoje tai nauja mokslinių tyrimų bei praktinio taikymo sritis.

Atliktu tyrimų tikslas - sukurti informacinès sistemos modelị, kuris padètų spręsti apleistuju pastatų 
racionalaus naudojimo teritorijų darnios plètros aspektu problemą. Sudarytos statinių bei teritorijos darnos rodiklius teikiančios geoinformacinès duomenų bazès, pritaikytos statiniu naudojimo prioritetams nustatyti, ivertinant daugiatikslị sprendimų pobūdị. Sprendimų prièmimo procesui patobulinti, duomenu rinkimo ir analizès patogumui bei vizualinio pateikimo galimybėms paịvairinti siūloma integruoti GIS ir MADM technologijas.

\section{Geoinformacinių duomenų bazių, skirtų daugiatiksliams uždaviniams spręsti, sudarymas}

\subsection{Duomenų bazių struktūra}

Siekiant priimti tinkamus sprendimus dèl racionalaus pastatu naudojimo, informacijai apie pastata, sklypą bei kitas aplinkos sąlygas parengti ir apdoroti gali būti naudojamos ivairios universaliosios informacinès sistemos ar kuriamos specialios sistemos. Šiuo atveju tenka kurti specialias duomenų bazes, tačiau tiesiogiai pasinaudoti žemės ir pastatų kadastrų ir registru duomenimis negalima, nes daugelis pavyzdyje nagrinėjamų neūkiškai naudojamų Lietuvos kaimo pastatų neinventorizuoti, ir duomenų apie juos esamose informacinèse sistemose nèra.

Duomenų bazių struktūra sudaryta atsižvelgiant ị tai, kuriems tikslams šie pastatai skirti, bei pradinių duomenų pobūdị. Eksperimentui parinktas vienas šalies rajonas (Utenos) ir parengtas rajono neūkiškai naudojamų bei šeimininko neturinčių kaimo pastatų geoinformacinès duomenų bazès pavyzdys [17]. Duomenų bazei sudaryti naudojamas ArcInfo 8 geoinformacinių duomenų bazès modelis. Sudarytoji asmeninė geoinformacinių duomenų bazè susideda iš dviejų tematinių duomenų grupių: topografinio pagrindo - KDB50LT ir duomenu apie pastatus grupès. Topografinių duomenų grupé sudaryta iš devynių M 1:50 000 sprendžiamam uždaviniui aktualių vektorinių topografinių duomenų sluoksnių. Pastatų geoinformacinių duomenų grupę sudaro taškinių geoinformacinių duomenų ir atributinių duomenų apie apleistus pastatus sluoksniai. Atributinè informacija parengta pagal Valstybinès teritoriju planavimo ir Statybos inspekcijos prie Aplinkos ministerijos bei Agrarinès ekonomikos instituto duomenis bei sudaryti keli nauji teminiu duomenu sluoksniai. Parengtos bazès atributinę pastatų informaciją sudaro dvidešimt aštuoni laukeliai (1 lentelè). Dešimt iš išvardytu pastatų atributų turi užkoduotus verčiu domenus. Esant poreikiui, yra galimybė geoinformacinių duomenų bazèje sudaryti naujus, papildomus atributinių duomenų domenus.

Sistemoje taip pat sukurti tematiniai Lietuvos teritorijos ir administraciniu vienetu (rajonu) geoinformacinių duomenų sluoksniai. Čia atributinès informacijos pavidalu sukaupta ir saugoma pagrindine informacija, reikalinga apleistų kaimo statinių naudojimo prioritetams nustatyti, siekiant darnios plètros šalyje perspektyvos, t. y. statistiniai Lietuvos administraciniu vienetų socialiniai, ekonominiai ir aplinkos duomenys. Šie duomenys surinkti pagal autorès pasiūlytą rodiklių sistemą apleistų pastatų naudojimo ar tvarkymo variantams aprašyti [18]. Bandomajam pavyzdžiui pasirinkti tokie rodikliai, kurių duomenis imanoma surinkti pagal apleistų pastatų problemai spręsti taikomą teritorini diferencijavima, bei duomenys, kurie yra oficialiai patvirtinti, pakankamai patikimi ir laisvai prieinami vartotojui, t. y. kuriuos pateikia Lietuvos statistikos departamentas (pav.). Visi erdviniai duomenys transformuojami į LKS'94 koordinačiu sistemą, pradiniai duomenys transformuojami geometriškai.

Parengtoje sistemoje galima atlikti izvairią pastatu ir vietovès geoinformacinių duomenų bazèse sukauptu duomenų analizę, atrinkti vartotojo nustatytas sąlygas atitinkančius duomenis. Sistemoje numatytos objektu skirstymo i kategorijas, sumavimo, apibendrinimo, atrinkimo pagal buvimo vietą, zonavimo ir kitos funkcijos, padedančios nustatyti pastatų tvarkymo ir naudojimo galimybes atsižvelgiant ị aplinkos sąlygas.

1 lentelè. Apleistų kaimo statinių geoinformacinių duomenų bazès atributinès informacijos laukeliai

Table 1. Attribute data of derelict rural buildings personal geodatabase

\begin{tabular}{|c|c|c|c|}
\hline Atributas & Aprašymas & Atributas & Aprašymas \\
\hline APSKRITIS & Apskritis, kurioje yra objektas & SIEN_ISARD_PR & Sienų suirimo mastas procentais \\
\hline RAJONAS & Rajonas, kuriame yra objektas & STOGAS & Iš kokios medžiagos pastato stogas \\
\hline SENIŪNIJA & Seniūnija, kurioje yra pastatas & STOG_NUS_PR & Stogo nusidèvèjimo procentas \\
\hline ADRESAS & Pastato adresas (dažnai - kaimas) & STOG_ISARD_PR & Stogo suirimo procentas \\
\hline PAVADINIMAS & Pastato tipas pagal paskirti & DURYS_LANGAI & Iš kokių medžiagų durys ir langai \\
\hline STATYBOS_METAI & Pastato statybos metai & DUR_L_NUS_PR & Durų ir langų nusidèvejjimo procentas \\
\hline SAVININKAS & Dabartinis pastato savininkas & DUR_L_ISAR_PR & Durų ir langų suirimo procentas \\
\hline SAVIN_IKI_PRIV & Pastato savininkas iki privatizavimo & PAMATAI & Pamatų tipas \\
\hline IKEITIMAS & Ar objektas ikeistas, ikeitimo data & PERDENGIMAS & Kokios perdangu konstrukcijos \\
\hline TEIS_REG_DATA & Pastato teisinio iregistravimo data & GRINDYS & Kokios medžiagos grindys \\
\hline INV_BYL_NR & Inventorinès bylos numeris & BENDR_NUS_PR & Bendras pastato nusidèvèjimo proc. \\
\hline MATMENYS & Pastato matmenys, $\mathrm{m} \times \mathrm{m}$ & SKLYPO_PRIKL & Žemès sklypo priklausomybė \\
\hline SIENOS_PERTV & Kokių medžiagų sienos ir pertvaros & STATYB_VERTE & Pastato statybinè vertė \\
\hline SIEN_NUSID_PR & Sienų nusidèvèjimo procentas & FOTO & Objekto fotonuotrauka \\
\hline
\end{tabular}




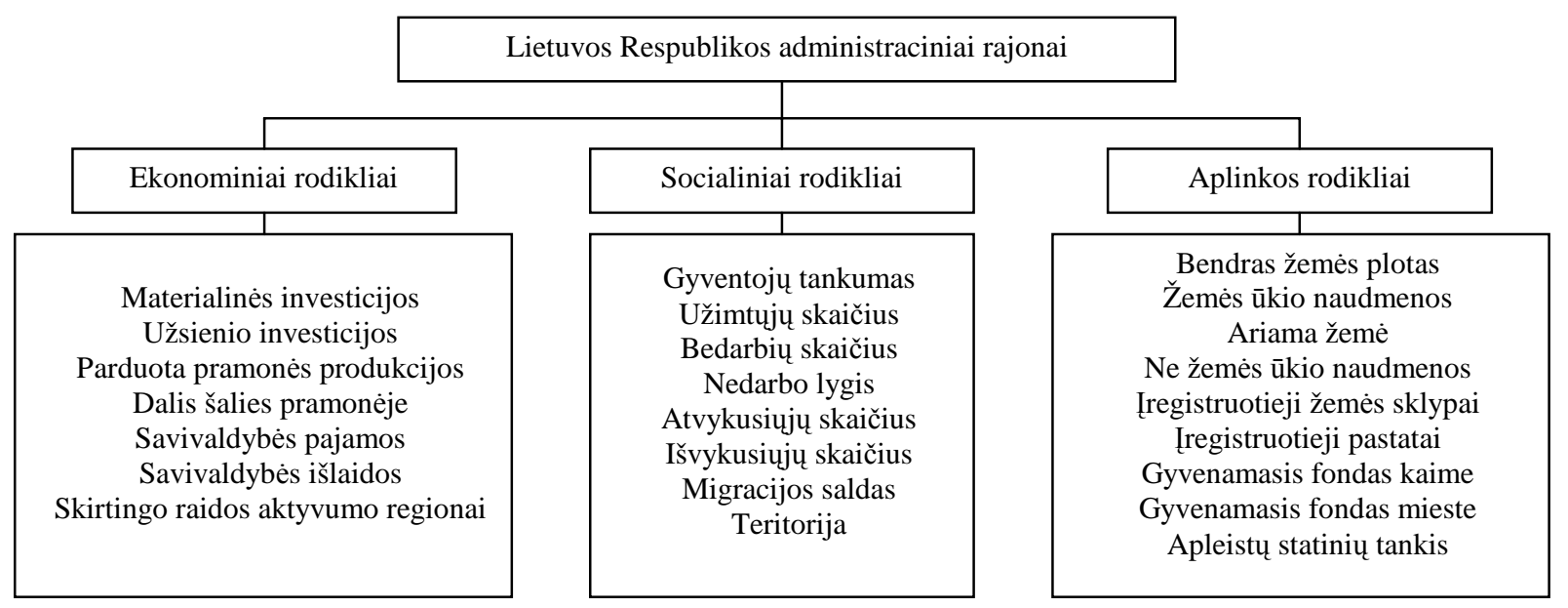

Darnios bendrosios ūkio plètros Lietuvoje rodiklių geoinformacinės duomenų bazès struktūra Geodatabase structure of Lithuanian sustainability indicators

\subsection{Alternatyvų prioritetų nustatymas pagal arčiausiojo priartejjimo prie idealiojo taško kriterijų}

C. L. Hwang ir K. Yoon 1981 m. [2] sukūrè projektų alternatyvų prioritetinès eilès nustatymo teoriją. Teigiama, kad optimali alternatyva yra mažiausiai nutolusi nuo idealaus sprendinio ir labiausiai nutolusi nuo idealiai neigiamo (blogiausiojo) sprendinio. Ši teorija vadinama variantų racionalumo nustatymu arčiausiojo priartejjimo prie idealiojo taško metodu (TOPSIS Technique for Order Preference by Similarity to Ideal Solution). Lietuvoje TOPSIS metodas gerai žinomas ir taikomas statybos uždaviniams spręsti nuo 1986 metų [19-21 ir kt.].

Uždavinys formuluojamas, sudarant sprendimu matricą iš $n$ alternatyvų, aprašytų $m$ rodikliais, t. y. sudaroma pradinè sprendimu prièmimo matrica $\left\{f_{i j}\right\}$, $i=1, \ldots, m ; j=1, \ldots, n$.

Norint palyginti skirtingų dimensijų rodiklius, sprendimų matrica normuojama, skirtingu dimensiju rodiklius perskaičiuojant i bedimensius [2-4]:

$$
r_{i j}=\frac{f_{i j}}{\sqrt{\sum_{j=1}^{n} f_{i j}^{2}}},
$$

čia $r_{i j}$ yra normuotasis matricos elementas, $i=1, \ldots, m ; j=1, \ldots, n$.

Svorinè sprendimų prièmimo matrica sudaroma normuotają matricą dauginant iš rodiklių reikšmingumo vektoriaus, t. y. kiekvienas matricos elementas dauginamas iš atitinkamo rodiklio reikšmingumo $q_{i}$ :

$$
v_{i j}=q_{i} \cdot r_{i j}, i=1, \ldots, m ; j=1, \ldots, n .
$$

Nustatomi idealusis $a^{*}$ ir neigiamai idealus $a^{-}$ variantai pagal $[1,5,12]$ pateiktas formules:

$$
\begin{aligned}
& a^{*}=\left\{\left(\max _{j} v_{i j} \mid i \in I\right),\left(\min _{j} v_{i j} \mid i \in I^{\prime}\right), j=1,2,3, \ldots, n\right\}= \\
& \left\{v_{1^{*}}, v_{2^{*}}, \ldots, v_{n^{*}}\right\}, \\
& a^{-}=\left\{\left(\min _{j} v_{i j} \mid i \in I\right),\left(\max _{j} v_{i j} \mid i \in I^{\prime}\right), j=1,2,3, \ldots, n\right\}= \\
& \left\{v_{1^{-}}, v_{2^{-}}, \ldots, v_{n^{-}}\right\},
\end{aligned}
$$

čia $I=\{i=1,2,3, \ldots, m\}-$ maksimizuojamų rodiklių aibè, $I^{\prime}=\{i=1,2,3, \ldots, m\}-$ minimizuojamų rodiklių aibè.

Nustatomas kiekvienos $a_{j}$ alternatyvos nuotolis iki idealiojo varianto $S_{j^{*}}$ :

$$
S_{j^{*}}=\sqrt{\sum_{i=1}^{m}\left(v_{i j}-v_{i^{*}}\right)^{2}}, j=1,2,3, \ldots, n .
$$

Nustatomas kiekvienos $a_{j}$ alternatyvos nuotolis iki neigiamai idealaus varianto $S_{j-}$ :

$$
S_{j-}=\sqrt{\sum_{i=1}^{m}\left(v_{i j}-v_{i-}\right)^{2}}, j=1,2,3, \ldots, n .
$$

Nustatomas santykinis alternatyvos $a_{j}$ priartejimas prie idealiojo varianto $a^{*}$ :

$$
C_{j^{*}}=\frac{S_{j-}}{S_{j^{*}}+S_{j-}}, j=1,2,3, \ldots, n,
$$

čia $1 \geq C_{j^{*}} \geq 0$.

Pagal $C_{j^{*}}$ reikšmes sudaroma alternatyvu prioritetinè eilè. Geriausia alternatyva ta, kurios $C_{j^{*}}$ reikšmė didžiausia. 


\subsection{Geoinformacinių duomenų parengimas daugiatikslei analizei}

Integruota gausi ir ivvairi informacija bei ivaairios duomenų analizès galimybės leidžia sudarytają sistemą naudoti kaip pagalbinę techninę priemonę apleistuju pastatu racionalaus naudojimo klausimams spręsti daugiatiksliais sprendimu priemimo metodais. GIS technologijos padeda aiškiai išdèstyti daugiatikslès analizès procesą, leidžia sudaryti didesnę grupę alternatyvu, analizuojant ittraukti naujus objektus bei atmesti nebetinkamus, taikant ivvairias užklausas ir loginius operatorius suteikia galimybę keisti analizèje naudojamus rodiklius, tame pačiame uždavinyje galima nagrinèti erdvinius ir neerdvinius duomenis.

Detaliai išnagrinèta pradinių duomenų parengimo specifika, ir duomenys pritaikyti sprendimams priimti taikant GIS technologijas ir MADM metodus [22]:

1. Sudarant duomenu bazes bei atrenkant rodiklius, aprašančius alternatyvius sprendinius, atsižvelgta i autorès pasiūlytą rodiklių sistemą ir darnios plètros šalyje koncepciją.

2. Nustatytos galimos alternatyvos, gautos taikant GIS technologijas. Alternatyvas nusako atitinkami rodikliai.

3. Daromos sluoksnių sanklotos ir rodikliai vaizduojami grafiškai:

3.1. Vektoriniai sluoksniai konvertuojami į rastrinius, kad būtų galima analizuoti visą teritoriją bei kiekvieną teritorijos elementą, o ne tik grafinius primityvus - taškus, linijas ar plotus.

3.2. Kiekvieno sluoksnio duomenys normuojami, pagal atitinkamas matematines funkcijas transformuojant $\mathfrak{i}$ bedimensius rodiklius, kintančius nuo 0 iki 1 (1).

3.3. Kiekvienam teminiam duomenų sluoksniui suteikiamas santykinis reikšmingumas (2).

3.4. Atliekama adityvioji svorinių normuotuju sluoksnių sanklota, sumuojant kiekvieno sluoksnio lastelę su atitinkama kito sluoksnio ląstele.

4. Gaunamas kombinuotasis žemėlapis, vaizduojantis galimas alternatyvas bei rodiklius.

\section{Erdvinio daugiatikslio uždavinio sprendimas}

Sudarytosios geoinformacinès sistemos fragmentas ir alternatyvų prioritetų nustatymo pagal arčiausiojo priartejjimo prie idealiojo taško kriterijų metodas (TOPSIS) pritaikyti konkrečiai problemai spręsti. Pasirinkti trys objektai ir siekta nustatyti tinkamiausias aplinkos sąlygas pastatams efektyviai atgaivinti. Analizuoti objektai iš triju Lietuvos administracinių rajonu, skirtingų raidos aktyvumo zonų: Telšių (aktyviosios raidos zona), Radviliškio (regresuojančiosios raidos zona) ir Anykščių (,buferinis“ regionas). Šie šalies skirtingose teritorijose esantys objektai atitinkamai ivardyti kaip sprendimo alternatyvos $A_{1}, A_{2}$ ir $A_{3}$. Jos aprašomos geoinformacinių duomenų bazèje sukaupta informacija - socialiniais, ekonominiais, techniniais ir aplinkos rodikliais. Žemėlapyje identifikuojamas objektas (pastatas, pastatų kompleksas ar teritorija) ir nustatoma geoobjekto atributinè informacija.

Taikant nustatytas rodiklių reikšmes, atliekami skaičiavimai TOPSIS metodu (1-7). Šio uždavinio sprendinio rezultatai pateikiami 2 lentelèje.

2 lentelè. Geriausios vietos, kurioje turètų būti atgaivinti apleistieji kaimo statiniai, nustatymas

Table 2. Selecting the best site for revitalisation of derelict rural buildings

\begin{tabular}{|c|c|c|c|}
\hline Analizès rezultatai & $\overline{A_{1}}$ & $A_{2}$ & $A_{3}$ \\
\hline 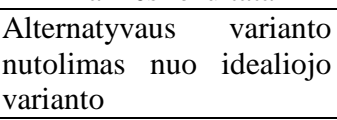 & 0,1049 & 0,0898 & 0,0682 \\
\hline $\begin{array}{l}\text { Alternatyvaus varianto } \\
\text { nutolimas nuo neigiamai } \\
\text { idealaus varianto }\end{array}$ & 0,0715 & 0,0797 & 0,1052 \\
\hline $\begin{array}{l}\text { Santykinis alternatyvaus } \\
\text { varianto priartejimas prie } \\
\text { idealiojo varianto }\end{array}$ & 0,4051 & $\mathbf{0 , 4 7 0 3}$ & 0,6064 \\
\hline $\begin{array}{lr}\text { Santykinis } & \text { alternatyvaus } \\
\text { varianto } & \text { naudingumo } \\
\text { laipsnis } & \\
\end{array}$ & $67 \%$ & $78 \%$ & $100 \%$ \\
\hline
\end{tabular}

Pagal apskaičiuotą santykini alternatyvų arčiausiaji priartejimą prie idealiojo varianto nustatyta tokia alternatyvu prioritetų eilè: $A_{3} \succ A_{2} \succ A_{1}$.

Skaičiavimu rezultatai palyginti ir nustatytas kiekvieno alternatyvaus varianto santykinis naudingumo laipsnis, palyginti su geriausiai ivertinto alternatyviojo varianto.

\section{Išvados}

1. Nustatyta, kad integruojamos $M A D M$ ir GIS technologijos papildo viena kitos privalumus, efektyviau sprendžiamos erdvinès daugiatikslès problemos: galima vertinti ir erdvinius, ir daugiatikslius nagrinejjamos problemos aspektus, struktūrizuoti sprendimą, apdoroti ivvairaus pobūdžio informaciją ir atlikti sisteminę bei kitokią analizę.

2. Eksperimentinio uždavinio rezultatai patvirtino, jog atgaivintų apleistų pastatų prioritetai, ivvertinant darnios plètros komponentus, priklauso nuo objektu išsidèstymo ir vietovès ypatumų. Rengiant apleistų pastatu atgaivinimo strategija, pastatu paskirties diferencijavima galima atlikti pagal teritorinius segmentus, aprašytus, taikant geografinę informacinę sistemą.

3. Realizuotas bandomasis pavyzdys parodè: kad sprendimų prièmimas taptų efektyvesnis, reikia plèsti sudaryto informacinès sistemos modelio geografinę ir atributinę informacija, kuriant naujus aktualių duomenų sluoksnius bei isisavinant ar pagal poreikius diegiant papildomas kompleksinès esamų duomenų analizès funkcijas. 


\section{Literatūra}

1. Heywood, I.; Kornelius, S.; Carver, S. An Introduction to Geographical Information Systems. $2^{\text {nd }}$ edition, Pearson Education Limited, 2002. 279 p.

2. Hwang, C. L.; Yoon, K. Multiple Attribute Decision Making Methods and Applications. Berlin, Heidelberg, New York: Springer - Verlag, 1981. 259 p.

3. Triantaphyllou, E. Multi-criteria Decision Making Methods: a Comparative Study. Kluwer Academic Publishers, 2000. 290 p.

4. Zavadskas, E. K.; Kaklauskas, A.; Banaitienè, N. Multiple Criteria Analysis of a Building's Life Cycle (Pastato gyvavimo proceso daugiakriterine analizè). Vilnius: Technika, 2001. 379 p. (in Lithuanian).

5. Joerin, F.; Theriault, M.; Musy, A. Using GIS and outranking multicriteria analysis for land-use suitability assessment. International Journal of Geographical Information Science, Vol 15, No 2, 2001, p. 153-174.

6. Joerin, F.; Musy, A. Land management with GIS and multicriteria analysis. International Transactions on Operational Research, No 7, 2000, p. 67-78.

7. Malczewski, J. GIS-based land-use suitability analysis: a critical overview. Progress in Planning, Vol 62, No 1, 2004, p. 3-65.

8. Yeh, A. G.; Hong, C. M. An integrated GIS and location allocation approach to public facilities planning - an example of open space planning. Computers, Environment and Urban Systems, Vol 20, 1996, p. 339-350.

9. Arentze, T. A. A spatial decision support system for the planning of retail and service facilities. Eindhoven University of Technology, 1999. $312 \mathrm{p}$.

10. MacDonald, M. A spatial decision support system for collaborative solid waste planning. In: Craglia, M.; Couclelis, H. (eds) Geographic Information Research: Bridging the Atlantics. London: Taylor and Francis, 1997, p. 510-522.

11. Janssen, R.; Goosen, H.; Verhoeven, M. L.; Verhoeven, J. T. A.; Omtzigt, A. Q. A.; Maltby, E. Decision support for integrated wetland management. Environmental Modelling \& Software, Vol 20, No 2, 2005, p. 215-229.

12. Geneletti, D. A GIS-based decision support system to identify nature conservation priorities in an alpine valley. Land Use Policy, Vol 21, No 2, 2004, p. 149-160.

13. Agrell, P. J.; Stam, A.; Fischer, G. W. Interactive multiobjective agro-ecological land use planning: The Bungoma region in Kenya. European Journal of Operational Research, Vol 158, No 1, 2004, p. 194-217.

14. Morari, F.; Lugato, E.; Borin, M. An integrated non-point source model-GIS system for selecting criteria of best management practices in the Po Valley, North Italy. Agriculture, Ecosystems \& Environment, Vol 102, No 3, 2004, p. 247-262.

15. Kangas, J.; Store, R.; Kangas, A. Socioecological landscape planning approach and multicriteria acceptability analysis in multiple-purpose forest management. Forest Policy and Economics, Vol 7, Issue 4, 2005, p. 603-614.

16. Malcziewski, J. GIS and Multi Criteria Decision Analysis. New York: John Willey \& Sons, 1999.

17. Gaidytė V.; Antuchevičienè, J. Geoinformation system model of derelict rural buildings. In: Proceedings of 6th Conference of Lithuanian Young Scientists "Lithuania without science-Lithuania without future". Civil Engineering (Statyba). Vilnius: Technika, 2003, p. 14-19 (in Lithuanian).

18. Antuchevičienė, J.; Zavadskas, E. K. The indicator model for sustainable revitalisation of rural property. Environmental Research, Engineering and Management, Vol 26, No 4, 2003, p. 38-44.

19. Zavadskas, E. K. The method of ranking of constructiontechnological alternatives on the basis of the distance from the ideal solution. In: New construction technology for buildings and structures (Новая технология возведения зданий и сооружений). Leningrad, 1986, p. 52-57 (in Russian).

20. Zavadskas, E. K.; Fiedler, K.; Peldschus, F. Decisionmaking Methods in Construction (Methoden der bautechnologischen Entscheidung). Leipzig: Technische Hochschule Leipzig, 1986 (in German).

21. Zavadskas E. K.; Antuchevičienè, J. Evaluation of buildings' redevelopment alternatives with an emphasis on the multipartite sustainability. International Journal of Strategic Property Management, Vol 8, No 2, 2004, p. 121-127.

22. Antuchevičienè, J.; Švedaite, A. The Application of Information Technologies for Identifying Rational Use of Derelict Buildings. In: Proceedings of 8th Conference of Lithuanian Young Scientists "Lithuania without science Lithuania without future". Civil Engineering (Statyba). Vilnius: Technika, 2005, p. 289-294 (in Lithuanian).

Jurgita Antuchevičienė. Associate Professor, Doctor. Vilnius Gediminas Technical University, Dept of Construction Technology and Management $(\mathrm{Ph}+37052745232)$.

A graduate of Vilnius Gediminas Technical University: First degree (1998), MSc (2001), PhD (2005). Author and coauthor of about 20 publications.

Research interests: multiple attribute analysis and decisionmaking theory, sustainable development, redevelopment of buildings, GIS. 